Provided for non-commercial research and education use. Not for reproduction, distribution or commercial use.

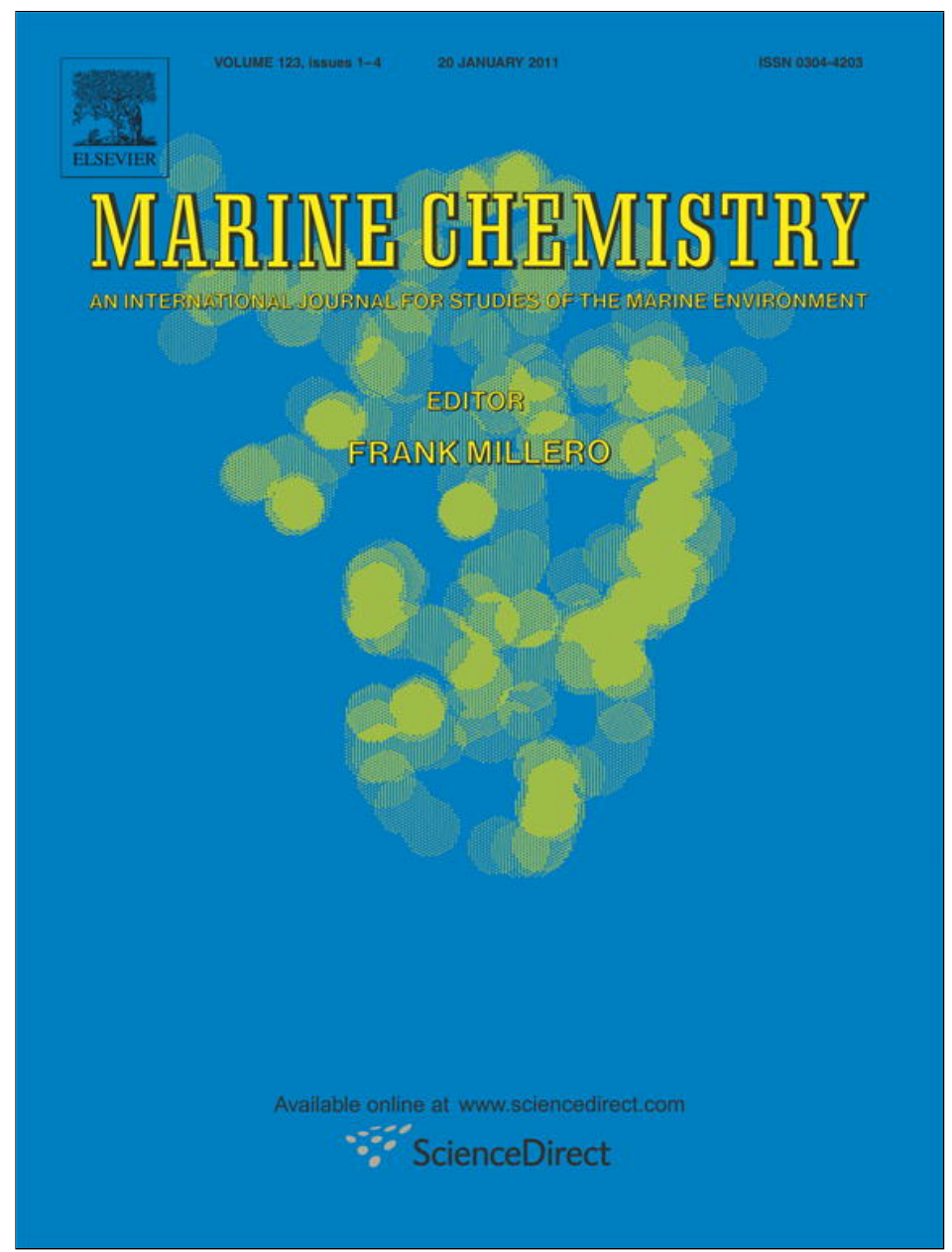

This article appeared in a journal published by Elsevier. The attached copy is furnished to the author for internal non-commercial research and education use, including for instruction at the authors institution and sharing with colleagues.

Other uses, including reproduction and distribution, or selling or licensing copies, or posting to personal, institutional or third party websites are prohibited.

In most cases authors are permitted to post their version of the article (e.g. in Word or Tex form) to their personal website or institutional repository. Authors requiring further information regarding Elsevier's archiving and manuscript policies are encouraged to visit:

http://www.elsevier.com/copyright 


\title{
Long lifetimes of $\beta$-glucosidase, leucine aminopeptidase, and phosphatase in Arctic seawater
}

\author{
Andrew D. Steen ${ }^{\mathrm{a}, \mathrm{b}, *}$, Carol Arnosti ${ }^{\mathrm{a}}$ \\ a Department of Marine Sciences, University of North Carolina at Chapel Hill, USA \\ b Center for Geomicrobiology, Aarhus University, Denmark
}

\section{A R T I C L E I N F O}

\section{Article history:}

Received 12 August 2010

Received in revised form 25 October 2010

Accepted 28 October 2010

Available online 3 November 2010

\section{Keywords:}

Extracellular enzyme

Arctic

Svalbard

Microbial loop

UV

Glucosidase

Phosphatase

Leucine aminopeptidase

\begin{abstract}
A B S T R A C T
The active lifetime of extracellular enzymes is a critical determinant of the effectiveness of enzyme production as a means for heterotrophic marine microbes to obtain organic substrates. Here, we report lifetimes of three classes of extracellular enzyme in Arctic seawater. We also investigated the relative importance of photochemical processes and particle-associated processes in inactivating extracellular enzymes. Enzyme inactivation in filtered seawater was slow, with apparent half-lives of enzyme activities on the order of hundreds of hours. The presence of particles (including cells) did not significantly change inactivation rates, suggesting that the long half-lives observed in filtered seawater were realistic for enzymes in unfiltered seawater. Phosphatase and leucine aminopeptidase were susceptible to photoinactivation, but only under high intensity UV-B and UV-C illumination; there was no evidence for increased inactivation rates under natural illumination at our study site in Ny Ålesund, Svalbard. Comparison of inactivation rates of commercially-obtained enzymes from non-marine sources with the extracellular enzymes naturally present in Arctic seawater suggests that the natural enzymes contain structural features that confer longer lifetimes, consistent with observations reported by others from a range of field sites that cell-free enzymes can contribute a substantial fraction of total hydrolytic activity in the water column.
\end{abstract}

(c) 2010 Elsevier B.V. All rights reserved.

\section{Introduction}

Heterotrophic microbes rely on extracellular enzymes to perform the initial step of organic matter remineralization by transforming high molecular weight (HMW) organic matter into molecules small enough to cross the cell membrane (Benz and Bauer, 1988). The dynamics of extracellular enzymes in solution therefore affect the nature and patterns of organic matter remineralization by aquatic microbial communities. Extracellular enzymes may be anchored to the bacterial outer membrane; they may also be released from the cell into solution, depending on microbial growth phase and nutrient state (Chróst, 1991, and references therein). Enzymes may also be released into solution as a result of viral lysis, or of zooplankton grazing (Bochdansky et al., 1995; Karner et al., 1994). Extracellular enzymes released into solution can provide sufficient substrate for cellular growth in pure culture (Vetter and Deming, 1999), and can at times constitute a considerable fraction of total enzyme activity in seawater (Baltar et al., 2010; Karner and Rassoulzadegan, 1995; Keith and Arnosti, 2001; Obayashi and Suzuki, 2008a,b). The active lifetime, as well as the physical location of extracellular enzymes thus influence the conditions under which microbial communities may "profitably"

* Corresponding author. Bygning 1540, Ny Munkegade 114, 8000 Åarhus C, Denmark. Tel.: +45 5070 9815; fax: +45 89422722 .

E-mail address: andrew.steen@biology.au.dk (A.D. Steen). remineralize high molecular weight organic matter (Allison, 2005 Vetter et al., 1998). Enzymes with longer lifetimes would be more valuable to the organisms that produce them (Allison, 2005; Vetter et al., 1998), and might catalyze degradation of organic matter farther from the organism that produced them.

Despite the importance of enzyme activities to heterotrophic microorganisms and to the marine carbon cycle as a whole, relatively little is known about the active lifetime of extracellular enzymes in seawater. Most studies of extracellular enzyme lifetimes have been conducted on purified enzymes from marine organisms in sterile buffer solution, or on ensembles of enzymes naturally present in fresh water. For example, a cold-active extracellular protease isolated from an Arctic marine bacterium had a half-life of approximately $12 \mathrm{~h}$ in sterile, buffered artificial seawater, and retained activity for $45 \mathrm{~h}$ when stabilized with extracellular polymeric substances (Huston et al., 2004). Commercially-available phosphatase and glucosidase had half-lives of 4 to $8 \mathrm{~h}$ in humic-rich lake water (Scully et al., 2003). The principal decay pathway in that case was an acid-catalyzed reaction with iron, a pathway that is not likely relevant at the higher $\mathrm{pH}$ of seawater. Interactions between ultraviolet (UV) radiation and humic substances also may have complex effects on enzyme inactivation in lake water (Boavida and Wetzel, 1998; Tietjen and Wetzel, 2003). Humic substances and UV radiation each initially decreased the activity of extracellular enzymes, but enzymes complexed with humic substances were apparently protected from 
inactivation via other pathways, and some humic-bound enzymes could apparently be re-activated by exposure to UV.

The rates and pathways of enzyme inactivation in seawater can be expected to differ from humic-rich and acidic freshwater environments described above. The goals of this study were to investigate decay rates of cell-free extracellular enzymes naturally present in Arctic seawater, and to assess the importance of photochemical processes on those decay rates. Extracellular enzymes from marine microbes might be structurally adapted for maximal lifetime in seawater (Vetter et al., 1998), so the use of naturally present extracellular enzymes may yield more realistic lifetimes than an investigation using commercially available enzymes, from non-marine sources, added to seawater. Assays of the lifetime of enzymes found naturally in seawater also avoid potential artifacts stemming from the fact that families of enzymes carrying out the same function can differ greatly in structure (Domań-Pytka and Bardowski, 2004).

In order to prevent production of new enzymes by seawater microbes, which would mask inactivation of the enzymes present at the time of sampling, we removed microbes by filtration $(0.2 \mu \mathrm{m})$ and measured the decay rates of enzymes naturally present in the filtrate. Incubations were kept short $(<36 \mathrm{~h})$ to minimize the importance of enzyme production by cells that may have passed through the filter. The role of visible and ultraviolet light in inactivating seawater enzymes was assessed by exposing natural enzymes to the full spectrum of natural sunlight, only the visible portion of the solar spectrum, and to UV light from an artificial source. An experiment comparing inactivation rates of commercially-obtained phosphatase in filtered and unfiltered seawater was conducted to investigate the extent to which inactivation rates measured in filtered water can be compared to rates in unfiltered seawater. These experiments provide an assessment of the lifetime of several extracellular enzymes in Arctic seawater, as well as the extent to which sunlight and particles act to influence those lifetimes. These results will help to define the contexts in which cell-free extracellular enzymes represent a viable strategy for resource acquisition by heterotrophic microbes in the cold waters.

\section{Methods}

\subsection{Sample collection}

Surface water samples from Kongsfjord, Svalbard $\left(78.93^{\circ} \mathrm{N}\right.$ $11.95^{\circ} \mathrm{E}$ ), were collected by bucket from the end of a pier in $\mathrm{Ny}$ Ålesund between August 16 and 22, 2007, immediately prior to performing the experiments. Water temperature was between $4^{\circ} \mathrm{C}$ and $7{ }^{\circ} \mathrm{C}$ at the time of sampling. Samples were processed in an environmental chamber at $7^{\circ} \mathrm{C}$. In experiments using filtered seawater, seawater was filtered through $0.22 \mu \mathrm{m}$ pore-size Durapore filters under a light vacuum $(<50 \mathrm{~mm} \mathrm{Hg})$.

\subsection{Measurement of enzyme activities}

Enzyme activities were measured using the fluorogenic substrate proxies 4-methylumbelliferyl-phosphate (MUF- $\mathrm{PO}_{4}$, to measure phosphatase activity), 4-methylumbelliferyl- $\alpha$-D-glucopyranoside and 4 -methylumbelliferyl- $\beta$-D-glucopyranoside (MUF- $\alpha$-glu and MUF- $\beta$ glu, to measure $\alpha$-glucosidase and $\beta$-glucosidase activities respectively), and L-leucine-7-amido-4-methylcoumarin hydrochloride (leuMCA, to measure leucine aminopeptidase activity) following King (1986) and Somville and Billen (1983). All substrates were obtained from Sigma-Aldrich. Fluorescence was measured using a Turner Biosystems TBS-380 fluorimeter, with excitation/emission channels set to the UV setting ( $365 \mathrm{~nm}$ excitation, $440-470 \mathrm{~nm}$ emission). In all experiments, the procedure to measure enzyme activities was as follows: $30 \mu \mathrm{L}$ fluorogenic substrate stock solution was added to a disposable methacrylate cuvette followed by $2 \mathrm{~mL}$ sample water for a final concentration of $300 \mu \mathrm{mol} \mathrm{L}-1$ (previously determined to be saturating concentrations for MUF- $\mathrm{PO}_{4}$, MUF- $\beta$-glu, and leu-AP) and mixed with a micropipettor. Fluorescence was measured immediately afterwards, and one to three more times over the course of $30 \mathrm{~min}$. Enzyme activity in each replicate was taken as the slope of the regression line of fluorescence versus incubation time. The number of replicates for each experiment is given in each figure legend. Abiotic hydrolysis of the fluorogenic substrate was assessed using autoclaved seawater; this value was subtracted from the measured enzymatic activities and was in all cases $<20 \%$ of the total hydrolysis rate. The fluorimeter was calibrated using standard solutions of 4-methylumbelliferone and 4-methylcoumarin in filtered seawater. Detector stability was monitored using a sealed standard (Turner Biosystems). Statistical analysis was carried out using the $\mathrm{R}$ statistical platform. No $\alpha$ glucosidase activity was detected in the saturation curve measurements, so $\alpha$-glucosidase activity was not assayed in any further experiments.

To assess the contribution of cell-free leucine aminopeptidase activity to total activity, leucine aminopeptidase activity was measured at $7{ }^{\circ} \mathrm{C}$ in $0.2 \mu \mathrm{m}$-filtered water and in unfiltered water.

\subsection{Inactivation of natural enzymes under natural light}

To assess the inactivation rates of the three classes of natural extracellular enzymes under sunlight, UV-free sunlight, and in the dark, nine sterilized polyethylene bags were filled with $250 \mathrm{~mL} 0.2 \mu \mathrm{m}$-filtered seawater and placed in low-walled tubs. Three bags were left uncovered in these tubs (full-spectrum treatment), three bags were covered in Lexan (visible light only treatment) and three were covered in aluminum foil (dark treatment). Polyethylene absorbs light weakly from 240-280 nm and is transparent above $280 \mathrm{~nm}$. Lexan is opaque below $400 \mathrm{~nm}$ and fully transparent above $440 \mathrm{~nm}$. The absorbance spectra of the specific materials used here were confirmed by spectrophotometry (data not shown). Temperature of the tubs was stabilized at $4-7^{\circ} \mathrm{C}$ by filling the tubs with $4{ }^{\circ} \mathrm{C}$ water, constantly supplied from a cooler. The bags were periodically subsampled through a sampling port by withdrawing $\sim 10 \mathrm{~mL}$ from each bag into a sterile syringe. The subsamples were transferred to a glass scintillation vial.

Phosphatase, $\beta$-glucosidase, and leucine aminopeptidase activities were measured as described previously, after warming the samples to $20{ }^{\circ} \mathrm{C}$ by immersing the scintillation vials in a $20^{\circ} \mathrm{C}$ bath for eight minutes. The purpose of this brief warming was to increase enzyme activity by a constant factor at each timepoint, in order to more precisely measure changes in enzyme activity as a function of time. As in other studies, the assumption is that $Q_{10}$ values (the dependence of enzyme activity on temperature) are constant, so this warming should not change the rate constant for enzyme inactivation that had occurred during incubation at $7{ }^{\circ} \mathrm{C}$. Because hydrolysis rates measured at $20^{\circ} \mathrm{C}$ do not reflect in situ rates, relative fluorescence units are reported rather than moles of monomer freed. Our focus is on determining the activity (under constant conditions) of the functional pool of enzymes at each time point, rather than on determining the in situ hydrolysis rates. Calibration curves indicated a conversion factor of $287 \mathrm{pM}$ MUF - (fluorescence unit) ${ }^{-1}$, and 610 pM MCA - (fluorescence unit) ${ }^{-1}$.

The weather conditions were cloudy during the experiment. Average global radiation in Ny Ålesund was $65 \mathrm{~W} \mathrm{~m}^{-2}$, of which $3.8 \mathrm{~W} \mathrm{~m}^{-2}$ was UV. Meteorological data was obtained from the Ny Ålesund observatory maintained by the Alfred Wegener Institute. The relative contributions of UV-A and UV-B radiation were not reported, but UV-B typically accounts for $1-2 \%$ of the total UV radiative power at Ny Ålesund (Hanelt et al., 2001); UV-B power was therefore $0.04-0.08 \mathrm{~W} \mathrm{~m}^{-2}$.

\subsection{Inactivation rates of commercial enzymes in artificial seawater}

Commercially-obtained phosphatase (Sigma P4252, from Escherichia coli), $\beta$-glucosidase (Sigma 49290, from almonds) and leucine 
aminopeptidase (Sigma L5006, from porcine kidney) were added to three replicate beakers of $100 \mathrm{~mL}$ autoclaved, artificial seawater (Sigma sea salts $59883,35.0 \mathrm{~g} \mathrm{~L}^{-1}$ ). Sigma-Aldrich confirmed that no secondary enzymes (e.g. proteases) were added to the purified enzymes as part of the production process (pers. comm). Final enzyme concentrations were $3 \mathrm{ng}$ phosphatase $\mathrm{mL}^{-1}, 2 \mu \mathrm{g} \beta$-glucosidase $\mathrm{mL}^{-1}$, and $12 \mu \mathrm{g}$ leucine aminopeptidase $\mathrm{mL}^{-1}$. Initial enzyme activities were

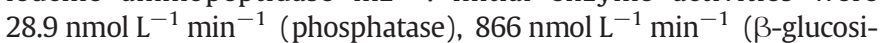
dase) and $71.2 \mu \mathrm{mol} \mathrm{L}^{-1} \mathrm{~min}^{-1}$ (leucine aminopeptidase). The experiment was carried out in an environmental room at $7^{\circ} \mathrm{C}$, and enzyme activity was measured periodically as described above, but at $7^{\circ} \mathrm{C}$. Because the activity of added commercial enzymes was much greater than that of cell-free enzymes naturally present in filtered seawater, activity was sufficiently high to be measured with precision at $7{ }^{\circ} \mathrm{C}$.

\subsection{Role of particles in inactivating commercial phosphatase}

To assess the importance of the presence of particles for the lifetime of dissolved extracellular enzymes, inactivation of commercially-obtained phosphatase (see previous section) was assessed in both unfiltered and filtered seawater collected from Kongsfjord as described above. Three sterile $50-\mathrm{mL}$ centrifuge tubes were each filled with $50 \mathrm{~mL}$ unfiltered seawater, and three others were filled with $50 \mathrm{~mL}$ filtrate. Phosphatase was added to each sample to a concentration of $12.2 \mu \mathrm{g}$ protein $\mathrm{L}^{-1}$. This quantity of phosphatase yielded an activity about 20 times greater than in situ phosphatase activity in unfiltered water, thus minimizing the relative contribution of any phosphatase enzymes produced by microbes in the unfiltered seawater, which could mask phosphatase inactivation. Centrifuge tubes with added phosphatase were incubated in the dark in an environmental room at $7{ }^{\circ} \mathrm{C}$, and enzyme activity was measured periodically (as described above) at $7^{\circ} \mathrm{C}$.

\subsection{Inactivation of natural enzymes in the presence of artificial UV illumination}

Filtered seawater was used to assess the susceptibility of natural dissolved enzymes to photochemical degradation. A $100 \mathrm{~mL}$ volume of filtered seawater was dispensed into each of six sterile Pyrex beakers, with UV-transparent polyethylene stretched across the beaker mouth (Pyrex itself is transparent in the visible but largely opaque in UV). Three beakers were wrapped completely in aluminum foil. All six beakers were placed in an environmental room at $7{ }^{\circ} \mathrm{C}$ directly under UV- and visible-emitting fluorescent lamps (UV: Q-Panel UVA-340, Cleveland, OH, USA; visible: Osram L65/25S, Munich, Germany). Visible photon flux was $18.6 \mu \mathrm{mol}$ photon $\mathrm{m}^{-2} \mathrm{~s}^{-1}$ (approximately $4.0 \mathrm{~W} \mathrm{~m}^{-2}$ ), UV-A power was $4.6 \mathrm{~W} \mathrm{~m}^{-2}$, and UV-B power was $0.4 \mathrm{~W} \mathrm{~m}^{-2}$.

Approximately $15 \mathrm{~mL}$ water was removed via sterile syringe from each beaker at each timepoint and placed in a clean $20 \mathrm{~mL}$ glass scintillation vial. Phosphatase, $\beta$-glucosidase, and leucine aminopeptidase activities were measured as described above, at $20^{\circ} \mathrm{C}$.

\section{Results}

\subsection{Inactivation of natural enzymes under natural light}

Natural cell-free enzymes, incubated in filtered seawater at $7{ }^{\circ} \mathrm{C}$ (and assayed at $20^{\circ} \mathrm{C}$ ) lost very little activity over the course of $36 \mathrm{~h}$ (Fig. 1). None of the treatments of phosphatase or leucine aminopeptidase showed a significant relationship between activity and time, whereas all of the treatments of $\beta$-glucosidase did (Table 1 ). Calculated half-lives of $\beta$-glucosidase centered on a range of $100-200$ h. No effect of light treatment was clearly distinguishable, indicating that natural sunlight had at most a modest effect on inactivation rates.

\subsection{Inactivation rates of commercial enzymes in artificial seawater}

All three commercially-obtained enzymes lost substantial activity over the course of $12-48 \mathrm{~h}$ when incubated at $7{ }^{\circ} \mathrm{C}$ in the dark in artificial seawater (Fig. 2). Phosphatase decay fit an exponential decay model well $\left(\mathrm{r}^{2}=0.82\right)$, with a half-life of $6.8 \mathrm{~h}$. The decay of leucine aminopeptidase and $\beta$-glucosidase did not correspond to first-order kinetics, with an initial rapid rate of inactivation and a later, slower phase, so half-lives were not calculated for those enzymes.

\subsection{Inactivation rates of commercial phosphatase in filtered and unfiltered seawater}

The activity of commercial phosphatase incubated in both filtered and unfiltered seawater at $7{ }^{\circ} \mathrm{C}$ in the dark decreased substantially during a 5-h incubation (Fig. 3). Unlike the incubation in artificial seawater, phosphatase inactivation appeared linear with time in both filtered and unfiltered seawater. Decay rates, calculated from a linear least-squares fit, were $12.0 \mathrm{nmol} \mathrm{L}^{-1} \mathrm{~h}^{-2}\left(\mathrm{r}^{2}=0.98\right)$ in unfiltered water, two times faster than the rate of $6.0 \mathrm{nmol} \mathrm{L}^{-1} \mathrm{~h}^{-2}\left(\mathrm{r}^{2}=0.95\right)$ in $0.2 \mu \mathrm{m}$-filtered water, although the difference in slopes was not significant (one-way analysis of covariance, $\mathrm{p}=0.42$ ).

\subsection{Inactivation rates of natural enzymes under artificial UV light}

Activities of natural phosphatases and leucine aminopeptidases decreased when exposed to artificial UV illumination (incubated at $7{ }^{\circ} \mathrm{C}$, assayed at $20^{\circ} \mathrm{C}$; Fig. 4). Natural $\beta$-glucosidases activities, however, did not change systematically. In order to isolate the effect of light from other causes of enzyme inactivation, results are reported as the ratio of activity in the light-exposed samples to activity in the dark-exposed samples, $r_{\text {time } t}=V_{U V}$, time $t / V_{\text {dark, time } t}$. The clear effect of artificial illumination on phosphatases and aminopeptidases contrasts with the weak or non-existent effect of natural radiation (compare Fig. 4 to Fig. 1 a,b,c). Initial enzyme activities in the dark

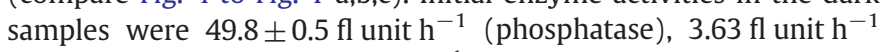
( $\beta$-glucosidase), and $31.5 \mathrm{fl} \mathrm{unit} \mathrm{h}^{-1}$ (leucine aminopeptidase). Initial activities in the light-exposed samples were all within the range of error of the dark values.

\subsection{Contribution of cell-free enzymes to total enzyme activities}

The only naturally present enzyme assayed in both filtered and unfiltered seawater at $7{ }^{\circ} \mathrm{C}$ was leucine aminopeptidase. Activity in unfiltered water was $563 \mathrm{nmol} \mathrm{L}^{-1} \mathrm{~h}^{-1}$, with $10 \pm 2.0 \%$ of that activity measured in filtered water.

\section{Discussion}

\subsection{Inactivation of natural and commercial enzymes in the dark}

Over 36-h dark incubations, all three commercially-obtained enzymes decayed much faster than their natural counterparts (Figs. 1-3). Natural enzymes - which are in fact enzyme classes, and may be represented by tens or more distinct enzymes (Arrieta and Herndl, 2002) - exhibited no detectable loss of activity over this time period, with only $\beta$-glucosidase unambiguously exhibiting any decay (28\% at the final timepoint, Fig. 1 ). The greater stability (longer half-lives) of the natural compared to the commercially-obtained enzymes may be due to intrinsic structural stability of the naturallyoccurring enzymes. Enzymes intended to function in the extracellular environment, a dilute aqueous medium compared to the crowded interior of a cell, likely have structural features that stabilize them relative to their intracellular counterparts.

Extracellular enzymes may also be protected against inactivation by association with DOM (Keil and Kirchman, 1994) and/or 

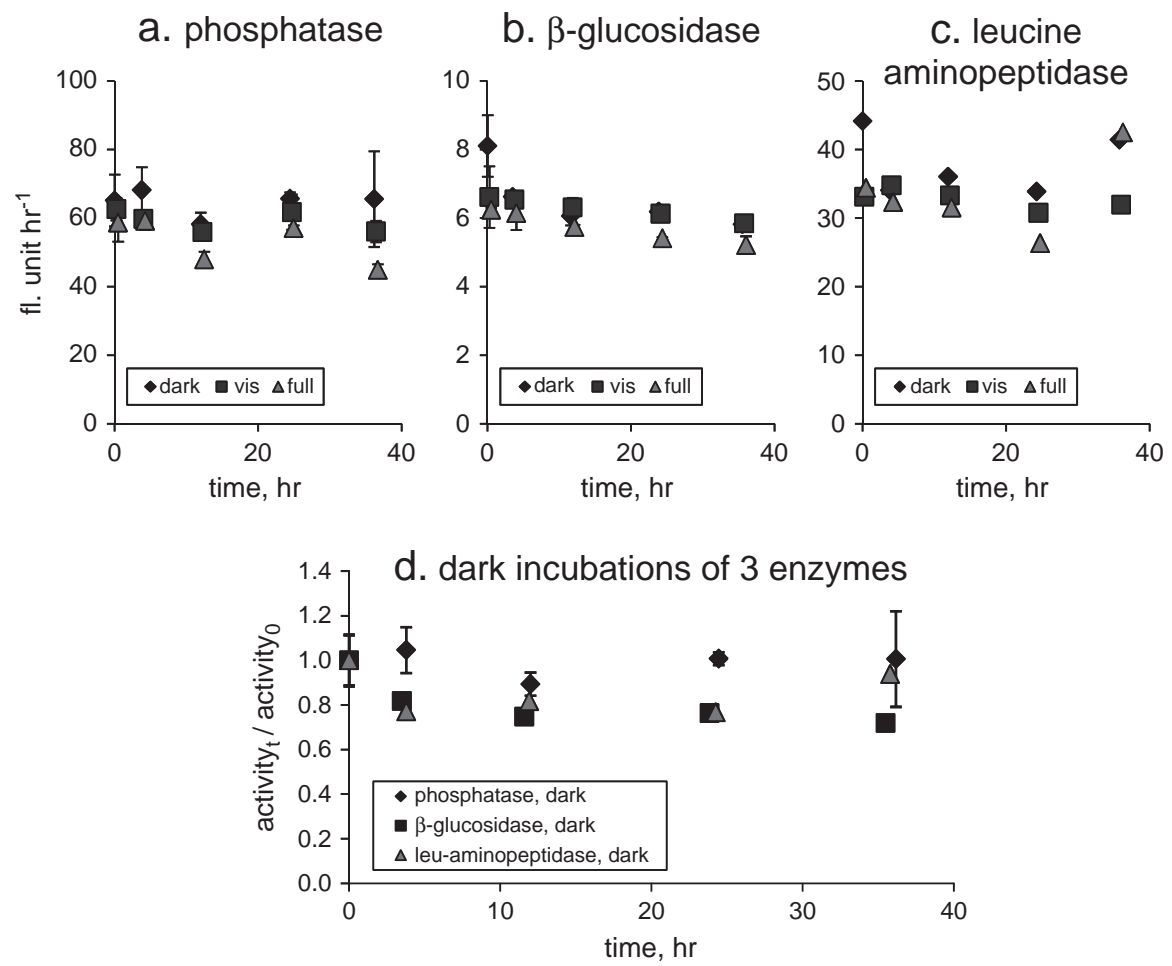

Fig. 1. Inactivation of natural phosphatase, leucine aminopeptidase, and $\beta$-glucosidase incubated outdoors at $4-7{ }^{\circ} \mathrm{C}$. Hydrolysis rates were measured at $20{ }^{\circ} \mathrm{C}$. Panels a, b, and c: activities of phosphatase ( 3 replicates), $\beta$-glucosidase ( 3 replicates), and leucine aminopeptidase ( 1 replicate), respectively, in the dark, exposed only to visible light, and exposed to full-spectrum sunlight. The 'visible' and 'full spectrum' data sets are offset by 0.25 and $0.5 \mathrm{~h}$, respectively, for clarity. Panel d: activities of phosphatase, leucine aminopeptidase, and $\beta$-glucosidase incubated in the dark, expressed relative to the activity of that enzyme at time zero. $\beta$-glucosidase and leucine aminopeptidase data are offset by 0.25 and $0.5 \mathrm{~h}$, respectively, for clarity. In all panels a, b, and d, error bars represent standard deviation of three replicates.

extracellular polymeric substance (EPS; Huston et al., 2004). Such associations with DOM or EPS could potentially also stabilize the commercially-available phosphatase against inactivation, although the relatively rapid inactivation of these enzymes in filtered and in unfiltered seawater (44\% loss of activity in unfiltered water and $21 \%$ loss of activity in filtered water over a 5-time course; Fig. 3) suggests that this mechanism is either not as effective for the commercial as for the natural enzymes (decay undetectable over $36 \mathrm{~h}$; Fig. 2), or that the protective effect of DOM/EPS was overwhelmed by the addition of the extra phosphatase enzymes to the seawater solution. Since the stoichiometry and mechanism of this protective effect are both unknown, however, the degree of saturation cannot be assessed. A definitive test of stabilization mechanisms (and measurement of the nature and extent of protection afforded by specific fractions of DOM and EPS) awaits considerable improvements in capabilities of determining the solution structure of enzymes, of DOM, and of EPS.

\subsection{Pathways of enzyme decay: light and particles}

Photochemical reactions have been implicated in the inactivation of extracellular enzymes (Espeland and Wetzel, 2001) and degradation of bulk DOM (Moran and Zepp, 1997) and DON (Vähätalo and Zepp, 2005). The increased inactivation rates of natural phosphatase and leucine aminopeptidase in the presence of bright, artificial UV demonstrate that phosphatase and leucine aminopeptidase were in principle susceptible to photochemical inactivation (Fig. 4). However, neither full spectrum natural sunlight nor the visible fraction of sunlight elicited a decrease in natural enzyme activity over $36 \mathrm{~h}$ (Fig. 1). Intensities of visible and UV-A light from the artificial light source were comparable to the outdoor incubation. The major difference between the natural and artificial light spectra was at the shorter UV wavelengths: UV-B (280-215 nm) was roughly 510 times more intense from artificial lamps than outdoors. Fluorescent lamps also typically emit some UV-C $(<290 \mathrm{~nm})$ radiation, whereas essentially no radiation shorter than $300 \mathrm{~nm}$ reaches the Earth's surface, even under an ozone-depleted atmosphere (Caldwell and Flint, 1994). The rapid inactivation of leucine aminopeptidase and phosphatase under artificial illumination was therefore likely due to shorter wavelengths than those that are relevant to natural systems. Photochemical reactions therefore do not appear to be a relevant pathway for the decay of these broad enzyme classes in Arctic seawater on the timescale of days.

In addition to intrinsic (structural) factors, interaction with DOM and EPS, and light intensity, interactions with particles-including live cells-may affect the inactivation rates of dissolved enzymes. This interaction can be envisioned in several forms: sorption of enzymes to cell or particle surfaces may extend the active lifetime of the enzymes (Ziervogel et al., 2007). Dissolved enzymes may also be the target of

Table 1

Results of model fits for natural enzymes incubated under natural light. Slope is linear least-squares fit. n.s. indicates Bonferroni-adjusted p $>0.05$.

\begin{tabular}{|c|c|c|c|c|c|c|c|c|c|}
\hline & \multicolumn{3}{|c|}{ Phosphatase } & \multicolumn{3}{|c|}{ Leucine aminopeptidase } & \multicolumn{3}{|l|}{$\beta$-glucosidase } \\
\hline & Dark & Vis & Full spectrum & Dark & Vis & Full spectrum & Dark & Vis & Full spectrum \\
\hline Slope, fl unit hr-1 & 0.0053 & -0.10 & -0.30 & -0.12 & -0.060 & 0.087 & -0.040 & -0.021 & -0.029 \\
\hline $\mathrm{p}$ value & n.s. & n.s. & n.s. & n.s. & n.s. & n.s. & $4.0 \times 10^{-3}$ & $5.1 \times 10^{-3}$ & $4.9 \times 10^{-5}$ \\
\hline Half-life, h (95\% conf limits) & - & - & - & - & - & - & $102(64,240)$ & $204(125,564)$ & $134(102,197)$ \\
\hline
\end{tabular}




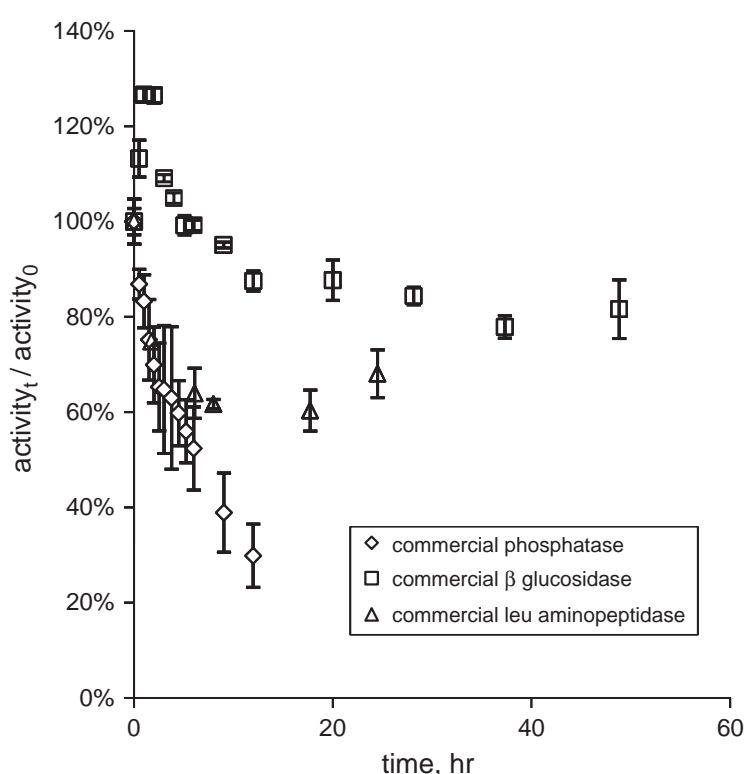

Fig. 2. Inactivation of commercially-obtained phosphatase, leucine aminopeptidase and $\beta$-glucosidase in artificial seawater, incubated at $7{ }^{\circ} \mathrm{C}$ in the dark and measured at $7{ }^{\circ} \mathrm{C}$ Activity is expressed relative to initial activity for each enzyme. Error bars represent standard deviation of 3 replicates.

particle- or cell-surface-associated proteases produced by heterotrophic communities, which would shorten enzyme lifetimes. In experiments with natural enzymes, the use of filtered seawater was an experimental necessity, to prevent the production of new enzymes by live cells from masking enzyme inactivation. We found that the decay rates of commercial enzymes in filtered seawater were generally similar to those in unfiltered seawater (Fig. 3). If natural enzymes are similarly affected by the presence of organisms/particles, the half-lives of tens to hundreds of hours are a realistic representation of the half-lives of natural dissolved enzymes in Arctic seawater.

\subsection{Implications of multi-day half-lives of extracellular enzymes in cold seawater}

In cold water, cell-free extracellular enzymes are stable for days or weeks, implying that enzymes may contribute to substrate availability at considerable distances (potentially meters to kilometers; see supplemental information) from the producing cell. The cost-benefit analysis of enzyme production under such circumstances might need to

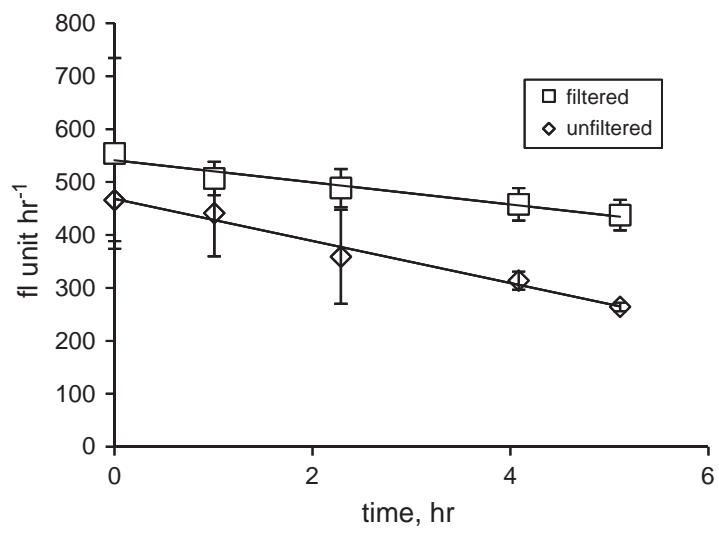

Fig. 3. Inactivation of commercially-obtained phosphatase incubated in filtered and unfiltered seawater at $7{ }^{\circ} \mathrm{C}$ in the dark and measured at $7{ }^{\circ} \mathrm{C}$. The line is a linear leastsquares regression of the data. Error bars represent standard deviation of 3 replicates.

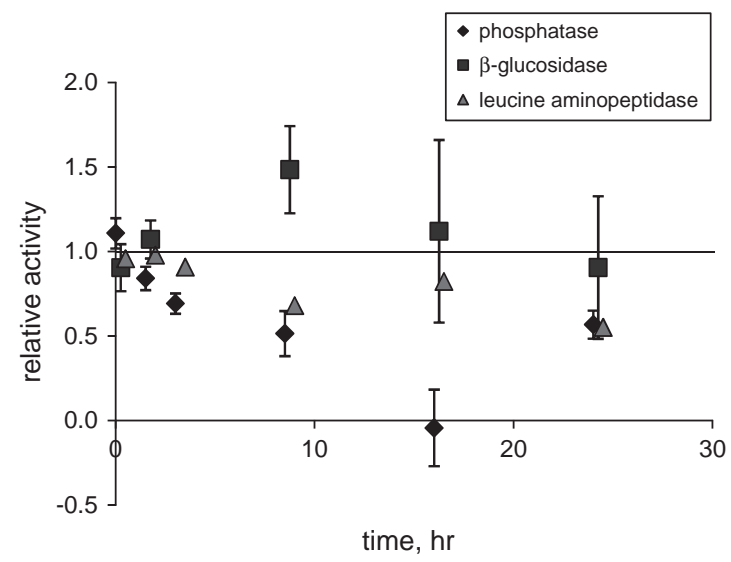

Fig. 4. Effect of artificial ultraviolet radiation on activities of natural phosphatase ( 3 replicates), leucine aminopeptidase ( 1 replicate), and $\beta$-glucosidase ( 3 replicates) in $0.2 \mu \mathrm{m}$-filtered seawater incubated at $7{ }^{\circ} \mathrm{C}$. Activities were measured at $20^{\circ} \mathrm{C}$. Activities are expressed as activity in UV-exposed seawater at each timepoint relative to the activity measured in the dark control at the same timepoint. Error bars for phosphatase and leucine aminopeptidase represent standard deviation of replicates. $\beta$-glucosidase and leucine aminopeptidase data are offset by 0.25 and $0.5 \mathrm{~h}$, respectively, for clarity.

include the possibility that cell-free enzymes may benefit a community of organisms working in concert to hydrolyze substrates. The observation that enzyme production may be linked to quorum-sensing mechanisms (Chernin et al., 1998; Givskov et al., 1997; Gram et al., 2002; Withers et al., 2001) supports such a perspective. In any case, the extent to which enzyme production would be 'profitable' for a microbial community would depend upon the return of substrate to the cells while they are still in proximity to the enzymes (Vetter et al. 1998).

Field evidence clearly shows that cell-free enzymes can contribute substantially to total hydrolytic activity. A range of $5 \%$ to nearly $100 \%$ has been reported for the contribution of cell-free extracellular enzymes to total enzyme activity in diverse aquatic environments, including estuarine, coastal, and deep-sea sites (Baltar et al., 2010; Karner and Rassoulzadegan, 1995; Keith and Arnosti, 2001; Obayashi and Suzuki, 2008a,b). The 10\% contribution of cell-free leucine aminopeptidase to total leucine aminopeptidase activity is on the low end of that range. To the best of our knowledge, these are the first data on cell-free extracellular enzyme activity from the Arctic. A recent report, however, found that the contribution of cell-free enzymes was particularly large in the deep sea, another permanently cold environment (Baltar et al., 2010). This latitudinal transect of the Atlantic showed cell-free enzymes consistently contributing $>60 \%$ of total activity in samples deeper than $100 \mathrm{~m}$, with contributions often close to $100 \%$. Such a high fraction is something of a puzzle, since model results suggest that cell-free enzymes would only be 'profitable' in the context of aggregates or other particles (Allison, 2005; Vetter et al., 1998). Baltar et al. (2010) suggested that disruption of colloidal material during sampling might have been responsible for the high fraction of cell-free activity. The results presented here suggest a second possibility: extracellular enzymes diffusing or advecting from aggregates (Ziervogel and Arnosti, 2008) would be stable over long timescales, and might make a substantial contribution to total enzyme activity against a low background of cellassociated enzyme activity in the deep ocean.

Stability of enzymes - both cell-free enzymes and those bound to particles - is an important parameter for the microbial loop, as well as for efforts to determine factors constraining the turnover rates of organic carbon in marine systems (Boudreau et al., 2008). Further investigation is required to understand more precisely how the specifics of enzyme structure, biological activity, and enzyme physical state (e.g. sorbed enzymes versus dissolved, DOM interactions, nature of sorbing surface) influence enzyme stability. More precise modeling efforts require accurate measurements of enzyme inactivation rates. 
The data presented here indicate that commercially-obtained enzymes may be a poor model for marine enzymes in such studies. The use of natural marine enzymes found in situ as in this study also has some significant complications: enzyme activities cannot easily be manipulated, and activity may be close to the detection limit. Further progress may be achieved by using enzymes released by pure cultures of organisms isolated from the relevant environment (e.g. Boavida and Wetzel, 1998; Huston et al., 2004). A thorough understanding of the dynamics of extracellular enzymes after they are produced by marine microbes will allow a more predictive understanding of the marine microbial loop.

\section{Acknowledgements}

We thank our colleagues from the Max Planck Institute for Marine Microbiology, particularly cruise organizer Casey Hubert, for enjoyable and well-organized fieldwork, as well as the staff of the Max Planck Institute and Elin Austerheim of King's Bay for logistical support in Ny Ålesund. We appreciate the experimental advice from Wade Jeffrey, and helpful comments on the manuscript from Ron Benner and Neil Blough as well as two anonymous reviewers. This work was carried out with support from the National Science Foundation (OCE-0323975 and OCE0848703 to C.A.) and the U.S. Environmental Protection Agency (EPA) under the Science to Achieve Results (STAR) Graduate Fellowship Program (to ADS). We also thank the Max-Planck Society for supporting the fieldwork.

\section{Appendix A. Supplementary data}

Supplementary data to this article can be found online at doi:10.1016/j. marchem.2010.10.006.

\section{References}

Allison, S.D., 2005. Cheaters, diffusion and nutrients constrain decomposition by microbial enzymes in spatially structured environments. Ecology Letters 8 , 626-635.

Arrieta, J., Herndl, G., 2002. Changes in $\beta$-glucosidase diversity during a coastal phytoplankton bloom. Limnology and Oceanography 47 (2), 594-599.

Baltar, F., et al., 2010. High dissolved extracellular enzymatic activity in the deep central Atlantic Ocean. Aquatic Microbial Ecology 58, 287-302.

Benz, R., Bauer, K., 1988. Permeation of hydrophilic molecules through the oute membrane of gram-negative bacteria. European Journal of Biochemistry 176, 1-19.

Boavida, M.-J., Wetzel, R.G., 1998. Inhibition of phosphatase activity by dissolved humic substances and hydrolytic reactivation by natural ultraviolet light. Freshwater Biology 40, 285-293.

Bochdansky, A.B., Puskaric, S., Herndl, G., 1995. Influence of zooplankton grazing on free dissolved enzymes in the sea. Marine Ecology Progress Series 121, 53-63.

Boudreau, B.P., Arnosti, C., Jørgensen, B.B., Canfield, D.E., 2008. Comment on "Physical model for the decay and preservation of marine organic carbon". Science 319 , $1616 \mathrm{~b}$

Caldwell, M.M., Flint, S.D., 1994. Stratospheric ozone reduction, solar UV-B radiation and terrestrial ecosystems. Climatic Change 28 (4), 375-394.

Chernin, L.S., et al., 1998. Chitinolytic activity in Chromobacterium violaceum: substrate analysis and regulation by quorum sensing. Journal of Bacteriology 180 (17) 4435-4441.

Microbial enzymes in aquatic environments. In: Chróst, R.J. (Ed.), Brock/Springer Series in Contemporary Bioscience. Springer-Verlag, New York. 317 pp.
Domań-Pytka, M., Bardowski, J., 2004. Pullulan degrading enzymes of bacterial origin Critical Reviews in Microbiology 30, 107-121.

Espeland, E.M., Wetzel, R.G., 2001. Complexation, stabilization, and UV photolysis of extracellular and surface-bound glucosidase and alkaline phosphatase: implications for biofilm microbiota. Microbial Ecology 42 (4), 572-585.

Givskov, M., Eberl, L., Molin, S., 1997. Control of exoenzyme production, motility and cell differentiation in Serratia liquefaciens. FEMS Microbiology Letters 148 (2), 115-122.

Gram, L., Grossart, H.-P., Schlingloff, A., Kiørboe, T., 2002. Possible quorum sensing in marine snow bacteria: production of acetylated homoserine lactones by Roseobacter strains isolated from marine snow. Applied and Environmental Microbiology 68 (8), 4111-4116.

Hanelt, D., et al., 2001. Light regime in an Arctic fjord: a study related to stratospheric ozone depletion as a basis for determination of UV effects on algal growth. Marine Biology 138, 649-658.

Huston, A.L., Methe, B., Deming, J.W., 2004. Purification, characterization, and sequencing of an extracellular cold-active aminopeptidase produced by marine psychrophile Colwellia psychrerythraea strain $34 \mathrm{H}$. Applied and Environmental Microbiology 70 (6), 3321-3328.

Karner, M., Rassoulzadegan, F., 1995. Extracellular enzyme-activity - indications for high short-term variability in a coastal marine ecosystem. Microbial Ecology 30 (2), 143-156.

Karner, M., Ferrier-Pagès, C., Rassoulzadegan, F., 1994. Phagotrophic nanoflagellates contribute to occurence of $\alpha$-glucosidase and aminopeptidase in marine environments. Marine Ecology Progress Series 114, 237-244.

Keil, R.G., Kirchman, D.L., 1994. Abiotic transformation of labile protein to refractory protein in sea water. Marine Chemistry 45, 187-196.

Keith, S.C., Arnosti, C., 2001. Extracellular enzyme activity in a river-bay-shelf transect: variations in polysaccharide hydrolysis rates with substrate and size class. Aquatic Microbial Ecology 24 (3), 243-253.

King, G.M., 1986. Characterization of $\beta$-glucosidase activity in intertidal marine sediments. Applied and Environmental Microbiology 51 (2), 373-380.

Moran, M.A and Zepp, R.G., 1997. Role of photoreactions in the formation of biologically labile compounds from dissolved organic matter. Limnology and Oceanography 42(6): 1307-1316.

Obayashi, Y., Suzuki, S., 2008a. Adsorption of extracellular proteases in seawater onto filters during size fractionation. Journal of Oceanography 64, 367-372.

Obayashi, Y., Suzuki, S., 2008b. Occurrence of exo- and endopeptidases in dissolved and particulate fractions of coastal seawater. Aquatic Microbial Ecology 50 (3), 231-237.

Scully, N.M., Tranvik, L.J., Cooper, W.J., 2003. Photochemical effects on the interaction of enzymes and dissolved organic matter in natural waters. Limnology and Oceanography 48 (5), 1818-1824.

Somville, M., Billen, G., 1983. A method for determining exoproteolytic activity in natural waters. Limnology and Oceanography 28 (1), 190-193.

Tietjen, T., Wetzel, R.G., 2003. Extracellular enzyme-clay mineral complexes: enzyme adsorption, alteration of enzyme activity, and protection from photodegradation. Aquatic Ecology 37, 331-339.

Vähätalo, A.V., Zepp, R.G., 2005. Photochemical mineralization of dissolved organic nitrogen to ammonium in the Baltic Sea. Environmental Science \& Technology 39, 6985-6992.

Vetter, Y.A., Deming. J.W., 1999. Growth rates of marine bacterial isolates on particulate organic substrates solubilized by freely released extracellular enzymes. Microbial Ecology 37, 86-94

Vetter, Y.A., Deming, J.W., Jumars, P.A., Krieger-Brockett, B.B., 1998. A predictive model of bacterial foraging by means of freely released extracellular enzymes. Microbial Ecology 36 (1), 75-92.

Withers, H., Swift, S., Williams, P., 2001. Quorum sensing as an integral component of gene regulatory networks in Gram-negative bacteria. Current Opinions in Microbiology 4, 186-193.

Ziervogel, K., Arnosti, C., 2008. Polysaccharide hydrolysis in aggregates and free enzyme activity in aggregate-free seawater from the north-eastern Gulf of Mexico. Environmental Microbiology 10 (2), 289-299.

Ziervogel, K., Karlsson, E., Arnosti, C., 2007. Surface associations of enzymes and organic matter: consequences for hydrolytic activity and organic matter remineralization in marine systems. Marine Chemistry 104, 241-252. 